\title{
Recent evolution of China's virtual water trade: analysis of selected crops and considerations for policy
}

\author{
J. Shi ${ }^{1,2}$, J. Liu ${ }^{1}$, and L. Pinter ${ }^{2,3}$ \\ ${ }^{1}$ School of Nature Conservation, Beijing Forestry University, Beijing, 100083, China \\ ${ }^{2}$ Department of Environmental Sciences and Policy, Central European University, Budapest, Hungary \\ ${ }^{3}$ International Institute for Sustainable Development, 161 Portage Avenue East, Winnipeg, MB R3B 0Y7, Canada
}

Correspondence to: J. Liu (junguo.liu@gmail.com; water21water@yahoo.com)

Received: 22 July 2013 - Published in Hydrol. Earth Syst. Sci. Discuss.: 17 September 2013

Revised: 19 February 2014 - Accepted: 28 February 2014 - Published: 8 April 2014

\begin{abstract}
China has dramatically increased its virtual water import over recent years. Many studies have focused on the quantity of traded virtual water, but very few go into analysing geographic distribution and the properties of China's virtual water trade network. This paper provides a calculation and analysis of the crop-related virtual water trade network of China based on 27 major primary crops between 1986 and 2009. The results show that China is a net importer of virtual water from water-abundant areas of North America and South America, and a net virtual water exporter to water-stressed areas of Asia, Africa, and Europe. Virtual water import is far larger than virtual water export, and in both import and export a small number of trade partners control the supply chain. Grain crops are the major contributors to virtual water trade, and among grain crops, soybeans, mostly imported from the US, Brazil and Argentina, are the most significant. In order to mitigate water scarcity and secure the food supply, virtual water should actively be incorporated into national water management strategies. And the sources of virtual water import need to be further diversified to reduce supply chain risks and increase resilience.
\end{abstract}

\section{Introduction}

Studies on virtual water trade have been carried out at different scales. At a global level, Hoekstra and Hung (2005) calculated the volume of crop-related international virtual water flows from 1995 to 1999 and found that, conservatively, $13 \%$ of the water used in crop production is for export in virtual water form. Chapagain et al. $(2005,2006)$ estimated that virtual water trade has saved $6 \%$ of global agricultural water use, which equals $28 \%$ of the total amount of virtual water flows associated with international agricultural trade. Further research by Hoekstra (2010) has also shown that current water use in agriculture is reduced by $5 \%$ through international virtual water trade. Dalin et al. (2012a) used a network approach to analyse the evolution of the global virtual water flows from 1986 to 2007. Their findings support the argument that global virtual water trade associated with international food trade has increased global water use efficiency and thus contributes to global water resource saving, although both regional and national virtual water trade patterns have changed a lot. Also, despite efficiency improvements, global and in many cases regional water withdrawals continue to increase in absolute terms, due to the combined effect of population growth and increasing affluence (Ozkaynak et al., 2012).

At a national level, water-poor economies can mitigate scarcity by actively importing water-intensive commodities instead of producing them domestically, while water-rich countries can also benefit economically by exporting virtual water from their abundant water resources. Allan (1998) pointed out that it is virtual water import that helps the Middle East avoid armed conflicts over its scarce water resources. He estimated that, by 2000, the Middle East and North Africa were importing virtual water associated with 50 million tons of grains annually. Shuval (2007) showed that Israel imports $80 \%$ of the national food consumption from abroad while Palestinians import more than $65 \%$ of their caloric intake. El-Sadek (2010) also showed that the share of net virtual water import of Egypt has amounted to $24 \%$ of its water 
resources. Other studies on Mediterranean countries such as Spain have shown that its virtual water import associated with grain trade is consistent with relative water scarcity, but the evolution of grain exports does not match the variations in resource scarcity, which suggests other factors including quality, product specification or the demand for a standardized product also influences virtual water trade (Novo et al., 2009).

China is a water-poor country in terms of water resource per capita and faces a trend of exacerbating water inequalities between water-abundant south and water-stressed north in general (Jiang, 2009; Liu et al., 2013). Studies (Liu et al., 2007; Liu and Savenije, 2008) have shown that the virtual water trade of China, which is influenced by both microand macro-economic conditions and weather fluctuations, has developed unconsciously, and they have suggested that active virtual water strategy could play a more important role in food security and sustainable water use, as China's agricultural commodity markets are liberalized. Yang and Zehnder (2001) analysed water scarcity in the North China Plain and pointed out that virtual water import should be taken as an additional measure in contrast with the conventional wisdom of "opening up new sources and economizing on the use of resources" to meet growing water demand.

Literature is available on the amount of virtual water traded between China and other countries, but there is a lack of research on the geographic distribution of China's virtual water trade network, how it has evolved over time, and what its implications for global and national water resources are. Also, the network properties of a China-centred virtual water trade network have never been analysed. This study aimed at reconstructing the evolution, geographic distribution and patterns of China's crop-related virtual water trade network over the last 2 decades and drawing corresponding policy implications.

\section{Methods}

\subsection{Selection of crops studied}

In order to portray the representative profile of crop-related virtual water trade network of China, we selected 27 primary crops which constitute around $80 \%$ of the total harvested area of the primary crops in China from 1986 to 2009 by average (FAOSTAT, 2014). They were categorized in four groups including eight grain crops, six fruit crops, six vegetable crops and seven cash crops. The categorization of selected crops followed Liu et al. (2007) to make the results comparable, which incorporated soybeans in grain crops as the traditional way of Chinese statistics and separated fruits and vegetables from cash crops.

\subsection{Crop yields}

Crop yields data were extracted from FAOSTAT (2014). Yields of all selected crops showed a general increasing trend over the studied period, with complicated oscillating patterns due to the mutual impacts from improvement of technologies, climate fluctuations, a warming trend possibly due to climate change, the associated growing concentration of atmospheric $\mathrm{CO}_{2}$, and changes in relevant social and economic policies.

\subsection{Virtual water content}

Virtual water content here is defined as the volume of water used in order to produce a unit of a crop. For primary crops, it is calculated by directly dividing the national average crop water requirement by corresponding crop yield in each year such as in Renault (2003), Zimmer and Renault (2003) and Liu et al. (2007). In this study, the same virtual water content of a type of commodity was used for China and other countries. This is in light of the fact that food export is a process of transferring virtual water from China to trade partners abroad, while food import can mitigate China's water scarcity by reducing water use in domestic food production. Table 1 shows the crop category, crop water requirement, crop yield and virtual water content of selected crops between 1986 and 2009.

\subsection{Virtual water trade}

Virtual water trade is associated with the international food trade of corresponding agricultural commodities, and consists of virtual water import and export. Trade data were adopted from FAOSTAT's (2014) detailed trade matrix. Each traded crop has its own country-specific and crop-specific virtual water content. Virtual water trade between two countries is calculated by multiplying the virtual water content by the traded amounts and adding the values obtained for all the traded crops. Virtual water balance is defined by subtracting virtual water export from virtual water import. If the value of virtual water balance is positive, then there is a net virtual water import; and if the value of virtual water balance is negative, then there is a net virtual water export. Virtual water flow is also referred to as virtual water trade in some literature. It better illustrates virtual water trade as an important anthropogenic way of hydrological process in a socioeconomic sphere. For convenience, the countries which import/export virtual water from/to China are denominated as "virtual water import partners" (VWIPs) and "virtual water export partners" (VWEPs). Since some countries can be importers and exporters simultaneously, "net VWIPs" and "net VWEPs" are also introduced in this study. 
Table 1. National average crop water requirements, crop yields (average between 1986 and 2009) and virtual water contents (average between 1986 and 2009) for selected crops. Data source for national average crop water requirements was Liu et al. (2007); data source for crop yields was FAOSTAT (2014).

\begin{tabular}{|c|c|c|c|c|}
\hline $\begin{array}{l}\text { Crop } \\
\text { category }\end{array}$ & Crop type & $\begin{array}{r}\text { National average } \\
\text { crop water } \\
\text { requirements } \\
\left(\mathrm{m}^{3} \mathrm{ha}^{-1}\right)\end{array}$ & $\begin{array}{r}\text { Yield } \\
\left(\text { t ha }^{-1}\right)\end{array}$ & $\begin{array}{r}\text { Virtual } \\
\text { water } \\
\text { contents } \\
\left(\mathrm{m}^{3} \mathrm{t}^{-1}\right)\end{array}$ \\
\hline \multirow{8}{*}{ Grain } & Rice (paddy) & 8000 & 6.03 & 1333 \\
\hline & Wheat & 4300 & 3.75 & 1171 \\
\hline & Maize & 4000 & 4.76 & 850 \\
\hline & Soybeans & 4900 & 1.61 & 3069 \\
\hline & Millet & 4440 & 1.86 & 2428 \\
\hline & Sorghum & 4000 & 3.70 & 1107 \\
\hline & Potatoes & 3040 & 13.42 & 231 \\
\hline & Barley & 4100 & 3.08 & 1377 \\
\hline \multirow{6}{*}{ Fruit } & Apples & 4500 & 7.67 & 864 \\
\hline & Citrus & 8850 & 10.97 & 1093 \\
\hline & Pears & 4850 & 7.76 & 692 \\
\hline & Watermelons & 3400 & 26.80 & 138 \\
\hline & Bananas & 12900 & 19.01 & 714 \\
\hline & Grapes & 5940 & 11.04 & 610 \\
\hline \multirow{6}{*}{ Vegetable } & Tomatoes & 4750 & 27.78 & 179 \\
\hline & Cabbages & 4010 & 27.01 & 155 \\
\hline & Carrots & 5600 & 22.43 & 257 \\
\hline & Cucumbers & 4900 & 20.49 & 269 \\
\hline & Lettuce & 3220 & 23.14 & 140 \\
\hline & Spinach & 2450 & 16.53 & 154 \\
\hline \multirow{7}{*}{ Cash } & Rapeseed & 3090 & 1.46 & 2177 \\
\hline & Sunflower & 4090 & 1.68 & 2465 \\
\hline & Sesame & 3400 & 0.92 & 4007 \\
\hline & Sugar beet & 5150 & 26.29 & 214 \\
\hline & Sugar cane & 9230 & 63.16 & 148 \\
\hline & Tobacco & 5000 & 1.79 & 2823 \\
\hline & Tea & 9500 & 0.77 & 12623 \\
\hline
\end{tabular}

Note: Liu et al. (2007) used National Bureau of Statistics of China (NBSC) data in the calculation of national average crop water requirements. The reasons are as follows. The national and provincial data are sufficient to analyse the virtual water trade patterns in China in this paper. Although more spatially explicit data sets are available, we do not need grid-based data for the virtual water trade analysis (and it is also difficult to do such analyses because trade data are not available at a grid cell level). For the national and provincial data, NBSC is the most commonly used data source. As yearly crop water requirement data are not available, we assume the same water requirement for a certain crop in different years in the same producing region.

\subsection{Virtual water trade network}

The virtual water trade relationships between China and "virtual water trade partners" (VWTPs) can be viewed collectively as a directed and weighted virtual water trade network (Dalin et al., 2012a). Each trade partner forms a node in the trade network in a given year, and virtual water flows associated with corresponding agricultural commodities form the links between nodes with the direction pointing to China as net virtual water import and the direction pointing from China as net virtual water export, respectively. The volume of traded virtual water between each pair of trade partners is the weight of the link. The number of trade partners is described by the node degree $k$, and the sum of weights is denoted by node strength $s$. The data reported by China were solely used irrespective of any divergence from the data reported by the other trade partners as the impact of such data divergence is assumed negligible, if any. It is also assumed that no direct trade was taking place if no data were reported between China and a certain country in a given year.

\section{Results}

\subsection{Crop-related virtual water trade of China}

China's crop-related VWTPs are from all six continents, but most are located in Asia, Europe and Africa. The total number of VWTPs has increased significantly since 1986, though the geographic distribution of VWTPs by continent has remained unchanged. In 1986, there are 24 VWTPs from Asia, Europe and Africa while there are 10 from North America, South America and Oceania. And in 2009, there are 125 VWTPs from Asia, Europe and Africa, and there are 34 from the Americas and Oceania. Note that, generally, Asia, Europe and Africa are net VWEPs while the Americas and Oceania are net VWIPs, from whom China imported much larger volumes of virtual water than that exported to net VWEPs. However, the patterns of import-export relationships have changed significantly over recent years, as the number of net VWIPs keeps rather steady, but the number of net VWEPs has drastically increased. Figure 1 shows the evolution of crop-related VWTPs of China over the period 1986-2009. Although there are more countries in Asia, Europe and Africa in total, there is no evidence showing that a simple relationship exists between the number of countries in one certain continent and the growth rate of the number of trade partners in that same continent. The building of trade partnership is driven by multiple factors including geographic distance, economic comparative advantage, international relationship etc. The correlation between the geographic location of the trade partners by continent and water endowment of the corresponding continent implies water endowment might be an important factor driving to form such a pattern.

China has a positive crop-related total virtual water balance with the total net virtual water import of $934 \mathrm{~km}^{3}$ and yearly average of $39 \mathrm{~km}^{3}$ over the period 1986-2009. Grain crops account for $97 \%$ of all virtual water imports and $53 \%$ for all virtual water exports. Despite the overwhelmingly dominant role of grain crops, cash crops also play an important role as they contribute to $46 \%$ for all virtual water exports. Furthermore, according to most recent trends, cash crops may replace grain crops as the largest contributor in total virtual water exports. As shown in 2008 and 2009, they accounted for 80 and $84 \%$, respectively, a double jump from $48 \%$ in 2007. Figure 2 shows the crop-related virtual water trade of China. 

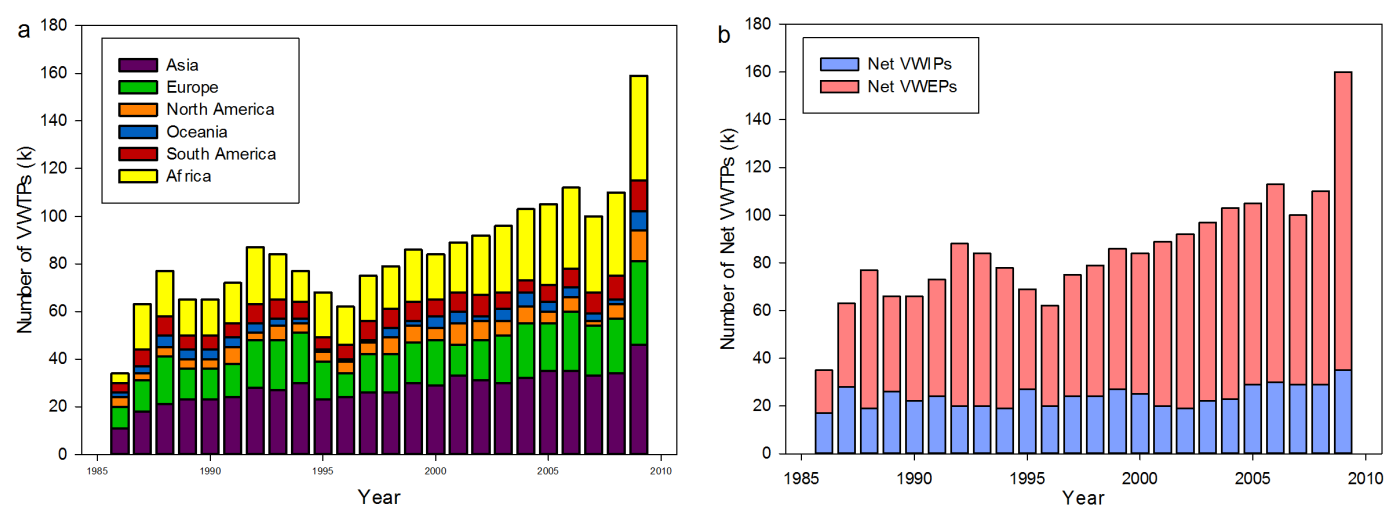

Fig. 1. (a) The evolution of geographic distribution in number of China's VWTPs by continent over the period of 1986-2009; (b) the evolution of import-export relationship in number of China's VWTPs over the period of 1986-2009. Net VWIPs (blue) represent trade partners from whom China imported virtual water, and net VWEPs (pink) represent trade partners to whom China exported virtual water.
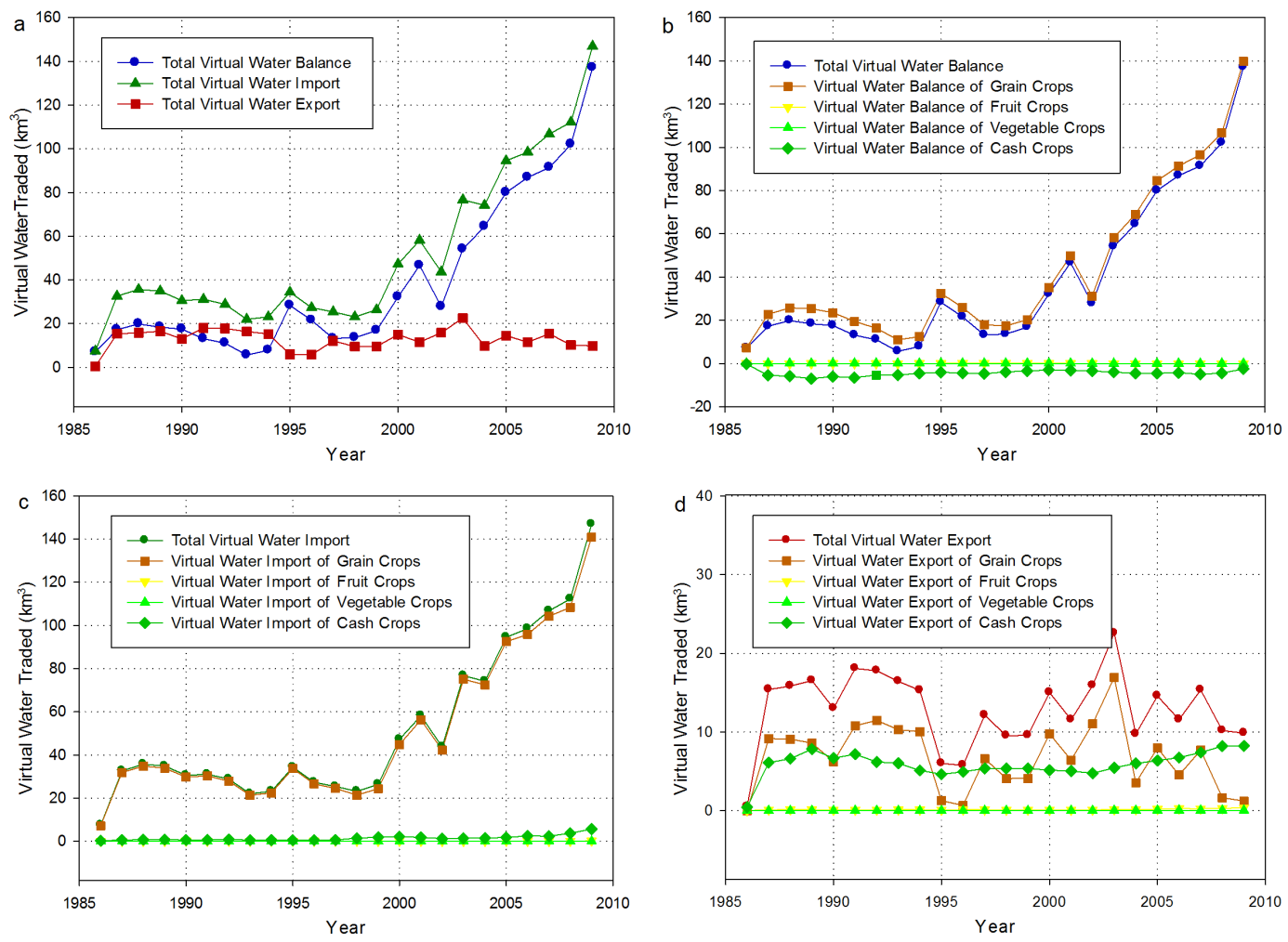

Fig. 2. Crop-related virtual water trade of China over the period of 1986-2009: (a) total virtual water trade of China; (b) contributions of different crops to total virtual water balance; (c) contributions of different crops to total virtual water import; (d) contributions of different crops to total virtual water export.

\subsection{Geographic distribution of virtual water trade network of China}

China mainly imported virtual water from North America before 2000 but added South America as another major trade partner of virtual water import afterwards. In 1986, China imported $6.70 \mathrm{~km}^{3}$ virtual water from North America, and in 2009 this number increased to $78.7 \mathrm{~km}^{3}$ but with another
$64.95 \mathrm{~km}^{3}$ from South America. Additionally, the accumulated amount of virtual water import from South America has been catching up with that of North America. The geographic distribution of virtual water export is more balanced and smaller in volume. Asia has generally been the major destination of virtual water export over the studied period of time, but Europe and Africa have also been important trade partners for China's exports. The distribution of virtual water 

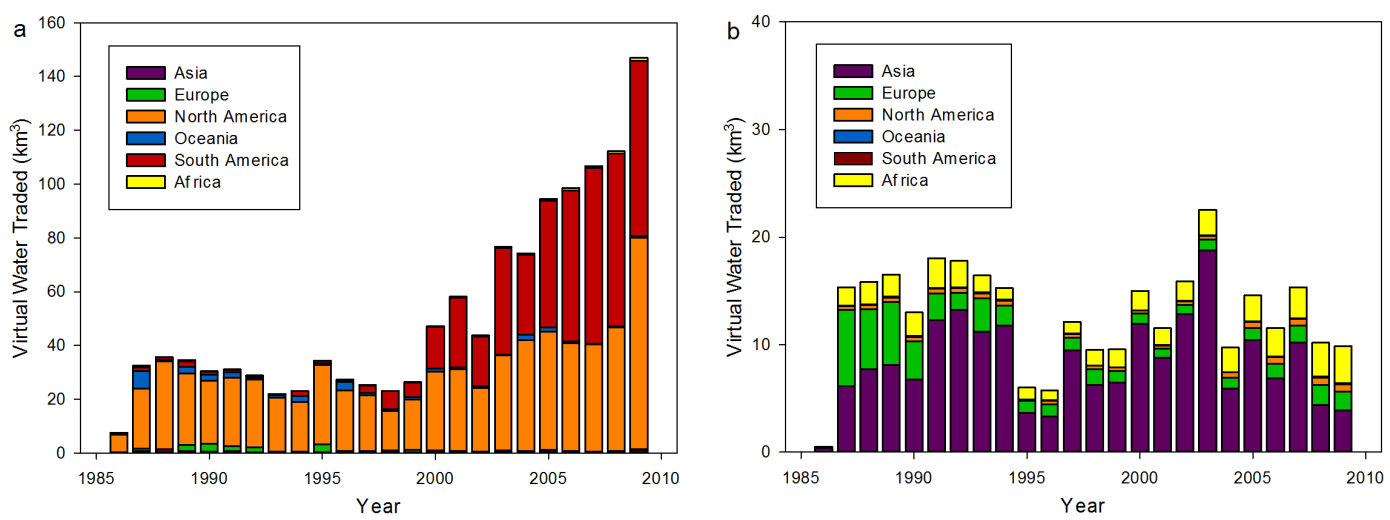

Fig. 3. The evolution of geographic distribution of China's virtual water trade over the period of 1986-2009: (a) geographic distribution of virtual water import; (b) geographic distribution of virtual water export.

export among these three continents has become even larger since 2008 (see Fig. 3).

Figure 4 combines the numbers of VWTPs and geographic distribution of virtual water trade to give a holistic view of the evolution of China's virtual water trade network over 19862009.

\subsection{Properties of virtual water trade network of China}

Considering trade links and the total amount of virtual water traded, the number of VWTPs generally grew from 35 in 1986 to 160 in 2009, an increase of four times, which mainly came from the increase of the number of net VWEPs from 18 in 1986 to 125 in 2009, most of which are located in Asia, Europe and Africa. But the number of net VWIPs remained rather steady, growing from 17 in 1986 only to 35 in 2009, which are mainly located in North America, South America and Oceania. In contrast to the relatively small number, net VWIPs contributed $81.15 \%$ of the total net virtual water traded with a percentage of $28.14 \%$ in number on yearly average. Also, the pattern of a small number (less than $30 \%$ ) of net VWIPs contributing to a large percentage (greater than $70 \%$ ) of total net virtual water traded has been unchanged over the studied period.

Further network analysis confirms that the virtual water trade network of China is heterogeneous and highly polarized. A few "big partners" (defined as trade partners who traded larger than average volumes of virtual water) dominated China's virtual water trade (see Fig. 5a and b). In terms of net virtual water import, the number of "big partners" was relatively small and rather steady. The yearly average number of "big partners" is 3.1, with an absolute deviation (referring to the absolute difference between an element in a data set and the mean value of that data set) of 0.45 , constituting $12.98 \%$ of the total number of net VWIPs. But they accounted for $95.97 \%$ of total net virtual water import. "Other partners" contributed mostly to the increase of the number of trade partners. The polarity is also prominent within net virtual water export. In net virtual water export, "big partners" have a yearly average number of 11.7 , with an absolute deviation of 3.6, constituting $18.97 \%$ of the total number of VWEPs. They took up $83.55 \%$ of the total net virtual water export.

Note that strength exceedance probability distribution of virtual water trade reconfirmed the highly polarized characteristics of China's virtual water network. The probability distribution shows the feature of a "fat tail" in each net virtual water trade network, net virtual water import network, and net virtual water export network, which highlights the fact that trade among a very small group of partners dominate the whole (see Fig. 5c). In fact, there are in total six countries which have traded more than $100 \mathrm{~km}^{3}$ virtual water each with China over 1986 and 2009. Among them, the US and Brazil each exported more than $500 \mathrm{~km}^{3}$ to China, and Argentina and Canada each exported 100 to $400 \mathrm{~km}^{3}$; while Japan and South Korea each imported over $100 \mathrm{~km}^{3}$ from China. Therefore any change in the trade with these "big partners" would impact on the whole trade pattern fundamentally. This is a disadvantage in terms of food security and resilience.

\subsection{A case in focus: soybeans}

China is the place of origin for soybeans and has been a net exporter before 1996. However the situation has changed, and soybean imports have increased dramatically. Soybeans show a prominent role in China's virtual water trade especially after 2000. The import of soybeans in 2003 exceeded total domestic soybean production in 2002 (FAOSTAT, 2014). Increasing domestic demand and the shift of food trade policy since China's accession to the WTO have both contributed to the jump of soybean import of China. The virtual water trade associated with soybean imports also reflects this highly polarized pattern in that a very small number of trade partners dominated the entire trade (see Fig. 6). Before 1996, the US was the only major trade partner, but since 2000 Brazil and Argentina have gradually become also major 

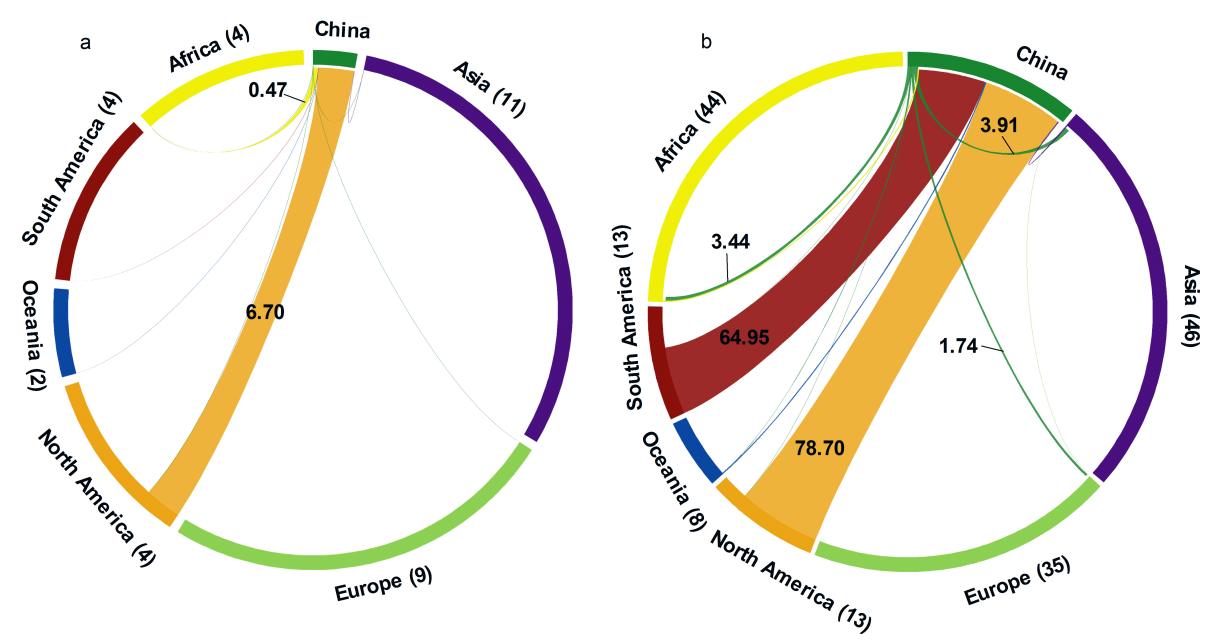

Fig. 4. Geographic distribution of China's virtual water trade in 1986 and 2009. The size of the segment represents the number of VWTPs in corresponding continent with labels in the brackets (the size of China is not in proportion); the size of the contribution track represents the volumes of virtual water traded with label unit of $\mathrm{km}^{3}$. Note that contribution track with the same colour as its connected segment shows that the virtual water is exported from the corresponding continent represented by that segment. (a) for 1986 and (b) for 2009 . Figures produced with Circos (Krzywinski et al., 2009).

suppliers. These three countries altogether exported $886 \mathrm{~km}^{3}$ of soybean-related virtual water to China over the period of 1986-2009 while all the other countries imported $29 \mathrm{~km}^{3}$ from China. The accumulated virtual water balance associated with soybeans accounted for $56.97 \%$ in the total virtual water balance of China between 1986 and 2009, and $78.26 \%$ between 2000 and 2009.

\section{Discussion}

\subsection{Comparison and analysis}

China has significantly raised its net virtual water import from $7.02 \mathrm{~km}^{3}$ in 1986 to $137.14 \mathrm{~km}^{3}$ in 2009 . The patterns of historic trend of virtual water trade are essentially the same, and values of traded virtual water are slightly smaller but comparable with Liu et al. (2007), which could be expected as more types of crops were used to calculate China's virtual water trade in their study. This dramatic rise in China's net virtual water import is mostly due to a major food trade policy shift in 2001 (Carter and Rozelle, 2001). China's virtual water import is far larger than virtual water export, and grain crops overwhelmingly dominate virtual water import, accounting for $97 \%$ on yearly average, which is also comparable with the result of over $95 \%$ from Liu et al. (2007). Grain crops are also important contributors in virtual water export with a share of $53 \%$, although not as dominant as in virtual water import. Virtual water export of fruits and vegetables is minor, but cash crops are significant, with a share of $46 \%$, among which virtual water export of tea is the most important source. This finding, again, goes along with the study of Liu et al. (2007) on China's virtual water trade between 1961 and 2004. The comparison suggests that the recent trend of China's virtual water trade has been kept since the policy turning point in 2001, and there is no indication its direction observed after 2004 will shift in the near future.

In terms of geographic distribution, there are many more VWTPs located in Asia, Europe and Africa than in the Americas and Oceania. The numbers of VWTPs located in different regions have all seen a great rise since 1986, but apparently most of the increase comes from Asia, Europe and Africa. This is in accordance with the spike of the number of VWEPs, which accounts for most of the increase in China's VWTPs. Despite of the increase in both VWTPs and traded virtual water, which is coherent with the general behaviour of the global virtual water trade network (Dalin et al., 2012a), there is a consistency of the geographic distribution in import-export relationship of virtual water trade: a net virtual water import from water-abundant areas of North America and South America, and a net virtual water export towards water-stressed areas of Asia, Africa, and Europe. This pattern has remained unchanged over the studied period. As crop water use efficiencies in North America and South America are generally higher than in Asia and Africa (Liu et al., 2009), and China shared $13 \%$ of global virtual water trade (Dalin et al., 2012a), China's crop-related virtual water trade positively contributes to optimizing crop water use efficiency at the global level, although global water withdrawals continue to increase in absolute terms (Ozkaynak et al., 2012). This is in line with the conclusion of Dalin et al. (2012a) that, on average at the global level (i.e. not taking regional differences into account), virtual water trade helps save the world water resources. But water endowment might not be the only 

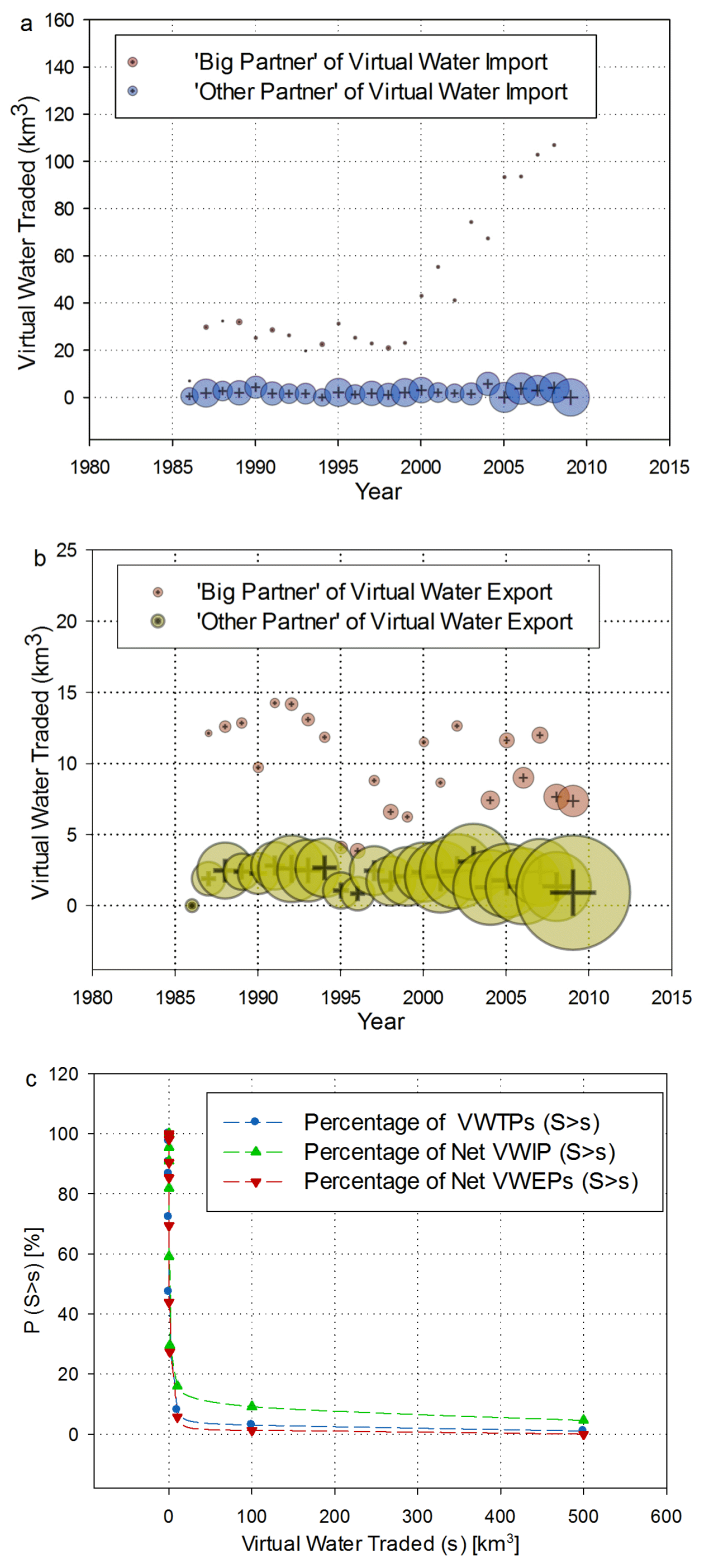

Fig. 5. (a) Polarization of China's net virtual water import network. The size of bubbles corresponds to the sum numbers of "big partners" and "other partners" in net virtual water import respectively; (b) polarization of China's net virtual water export network. The size of bubbles corresponds to the sum numbers of "big partners" and "other partners" in net virtual water export respectively; (c) node strength exceedance probability distribution of virtual water trade network of China. We used the accumulated amount of traded virtual water of each trade partner between 1986 and 2009.

factor affecting virtual water flow directions at a lower scale - for example at the regional or national levels especially when considering commodities beyond food (D'Odorico et al., 2012; Tamea et al., 2013). The most prominent feature of China's virtual water trade network is the high heterogeneity; that is, within both import and export a small group of

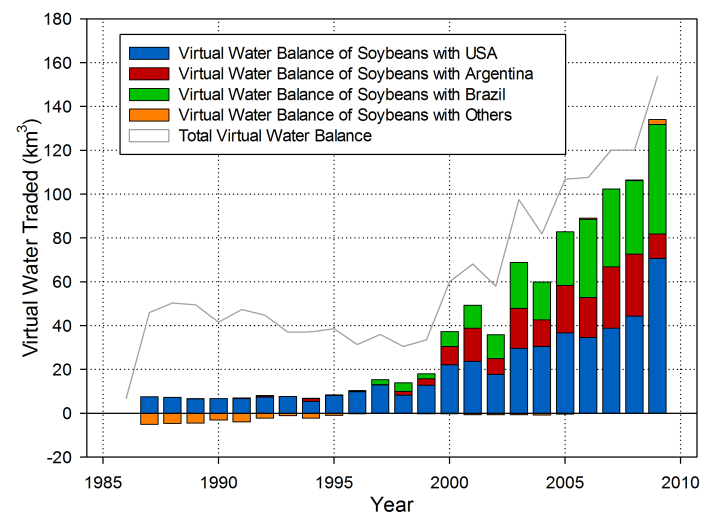

Fig. 6. Virtual water trade network associated with soybeans of China over the period of 1986-2009.

VWTPs control the entire trade. This is also coherent with the global virtual water trade network characteristics that a small number of global actors control a significant portion of virtual water export, which reflects Pareto principle in the context of virtual water trade network (Carr et al., 2012a, b, 2013).

Notably, soybeans, nearly all imported from the US, Brazil and Argentina (in fact, the soybean-associated virtual water balance of other countries is minor and negative), account for $91.7 \%$ of China's virtual water trade on yearly average. This is similar to $90 \%$ calculated by Dalin et al. (2012a) and driven by growing economic growth and demand and changing preferences towards a more meat-based diet (Liu et al., 2008). Together with the lifting of food trade barriers, it explains the dramatic increase of China's virtual water import. The large demand for soybeans in China has not only changed China's virtual water trade network but also has influenced the structure of agriculture in the western hemisphere. Despite its negative impact on worsening the deforestation in the Amazon Basin, this trend also has trade and water-resource-sustainability-related advantages, since the Americas have comparative advantages due to higher yields. In addition, crop water productivity of soybean is higher in the Americas than in China (Liu et al., 2009). Hence, scale issues aside, China's soybean imports from the Americas help save water resources at the global level as more water would be consumed if China produced those soybeans domestically. Strictly speaking, this is also consistent with the goals of the General Agreement on Tariffs and Trade (GATT) to "take full advantage of the world's resources, and expand the production and circulation of goods".

\subsection{Policy implications}

The results show that grain crops have been the major source of imported virtual water of China, which is significantly contributed by the dramatic increase of soybean import. And this recent trend has been kept since the policy turning point 
in 2001. China is facing increasingly severe water scarcity (Jiang, 2009; Liu et al., 2013). On the demand side, the need for water resources in China will continue to grow, driven by population pressure, increasing affluence (e.g. increasing role of meat in the diet) and rapid growth of a resourceintensive economy. On the supply side, water resources in China are increasingly stressed. The uneven distribution of water resources between northern and southern China is projected to worsen due to further climate change, and available water resources will be further reduced by expanding water pollution (Piao et al., 2010; Mountford, 2011; Wang and Zhang, 2011). Therefore, China needs a more integrated water management strategy, including an active virtual water policy.

An active virtual water trade policy could be a wise additional option to complement integrated measures that focus on addressing water supply and demand issues at the national level. This is not without precedent, as policy measures to mitigate the water scarcity through virtual water trade policy have been successfully implemented in other water-stressed countries, especially in the Middle East and North Africa (Allan, 1998; Shuval, 2007; El-Sadek, 2010). Whether China will take virtual water strategy as an active water policy, it can be expected that China will continue to increase the import of grain crops and their associated virtual water. This may further impose pressure on the supply chain of international staple crop market and continue to drive up the food price, as being seen in the case of soybeans. In turn, this would recall the long-standing concern about the food sovereignty and security of China. There is a widely held view that China needs to maintain a relatively high level of self-sufficiency of grain crops (about $95 \%$ ). While the accelerating integration of China into the world economy, especially China's accession to the WTO, has resulted in a loosening of policies on food trade, maintaining a high rate of selfsufficiency in grains is becoming more and more unnecessary and unfeasible, neither economically nor environmentally.

Taking the high heterogeneity of virtual water import in China via the tight coupling of the supply chain with a small group of countries into account, in order to reduce the risk of volatile international food market and increase resilience, the sources of virtual water import should be further diversified. In this study, we found China has already increased major VWTPs (i.e. shifting from North America alone to both North America and South America). This helps control the supply chain risk, and China should continue to strive for diversifying major trade partners. Furthermore, considering the fact that most of the virtual water resources available for export tend to remain concentrated in a small set of countries (Carr et al., 2013), which can be also seen from our results that most of VWIPs are located in Americas with a limited number, and the projection that the future structure of global virtual water trade network will become increasingly heterogeneous (Dalin et al., 2012b), it is not sufficient to diversify VWIPs as an element of an improved virtual water trade strategy. The structure of agriculture also needs to be adjusted. As discussed by Huang and Rozelle (2002), the structure of agricultural adjustment includes structural changes in the agricultural commodity mix, quality improvement of major commodities and the promotion of regional specialization.

Our results also indicate that cash crops may replace grain crops as the largest contributor in total virtual water export of China. Liu et al. (2007) pointed out that the goal of the structural adjustment of agriculture is to achieve so-called "threehigh" agriculture: high output, high quality, and high efficiency. They showed that most crops that turn water into high economic value are low on water intensity, and they are more suited to water-saving irrigation; thus, shifting to high water value crops can increase farmers' incomes without increasing agricultural water consumption (Liu et al., 2007). Therefore, there also should be financial incentives to reduce exporting highly water-intensive but low-economic-value agricultural products, and to increase exporting crops characterized by low water intensity but high economic value. It is crucial to strive for a more efficient agricultural use of water as an element of a virtual water trade strategy. Our results show that Asia, Africa, and Europe have been the main and fastest growing destinations of China's exported virtual water. Those are also water-stressed regions in general, which implies greater potential markets for China's virtual water export.

Acknowledgements. This study was based on the M.Sc. thesis for the Department of Environmental Sciences and Policy of Central European University, which was supervised by Junguo Liu and László Pintér. We also thank Alan Watt, Brandon Anthony, and Ruben Mnatsakanian for their support to this study. This study was supported by the International Science and Technology Cooperation Program of the Ministry of Science and Technology of China (2012DFA91530), the National Natural Science Foundation of China (91025009; 41161140353), the Special Fund for Forestry Scientific Research in the Public Interest (no. 201204204), the 1st Youth Excellent Talents Program of the Organization Department of the Central Committee of the CPC, and the Fundamental Research Funds for the Central Universities (TD-JC-2013-2).

Edited by: M. Sivapalan

\section{References}

Allan, J. A.: Watersheds and problemshed: Explaining the absence of armed conflicts over water in the Middle East, Mid. East Rev. Int. Affair., 2, 49-51, 1998.

Carr, J. A., D’Odorico, P., Laio, F., Ridolfi, L., and Seekell, D.: Inequalities in the networks of virtual water flow, EOS Trans. AGU, 93, 309, doi:10.1029/2012EO320001, 2012a.

Carr, J. A., D’ Odorico, P., Laio, F., and Ridolfi, L.: On the temporal variability of the virtual water network, Geophys. Res. Lett., 39, L06404, doi:10.1029/2012GL051247, 2012b. 
Carr, J. A., D’Odorico, P., Laio, F., and Ridolfi, L.: Recent history and geography of virtual water trade, PLoS ONE, 8, e55825, doi:10.1371/journal.pone.0055825, 2013.

Carter, C. A. and Rozelle, S.: Will China's agricultural trade reflect its comparative advantage? China's Food and Agriculture: Issues for the 21st Century, edited by: Gale, F., ERS, USDA, AIB, 775, 27-30, 2001.

Chapagain, A. K., Hoekstra, A. Y., and Savenije, H. H. G.: Saving water through global trade, Value of Water Research Report Series No. 17, UNESCO-IHE, Delft, the Netherlands, 2005.

Chapagain, A. K., Hoekstra, A. Y., and Savenije, H. H. G.: Water saving through international trade of agricultural products, Hydrol. Earth Syst. Sci., 10, 455-468, doi:10.5194/hess-10-4552006, 2006.

Dalin, C., Konar, M., Hanasaki, N., Rinaldo, A., and RodriguezIturbe, I.: Evolution of the global virtual water trade network, P. Natl. Acad. Sci., 109, 5989-5994, 2012a.

Dalin, C., Suweis, S., Konar, M., Hanasaki, N., and RodriguezIturbe , I.: Modeling past and future structure of the global virtual water trade network, Geogr. Res. Lett., 39, L24402, doi:10.1029/2012GL053871, 2012b.

D’Odorico, P., Carr, J. A., Laio, F., and Ridolfi, L.: Spatial organization and drivers of the virtual water trade: a community-structure analysis, Environ. Res. Lett., 7, 034007, doi:10.1088/17489326/7/3/034007, 2012.

El-Sadek, A.: Virtual water trade as a solution for water scarcity in Egypt, Water Resour. Manage., 24, 2437-2448, 2010.

FAOSTAT: FAO Statistical Database, Food and Agricultural Organization of the United Nations, Rome, Italy, available at: http: //faostat.fao.org/, last access: 8 February 2014.

Hoekstra, A. Y.: The relation between international trade and freshwater scarcity, Working Paper presented in the WTO working paper series as commissioned background analysis for the World Trade Report 2010 on "Trade in Natural Resources: Challenges in Global Governance", available at: http://www.wto.org/english/ rese/reser_e/ersd201005e.pdf (last access: 7 July 2012), 2010.

Hoekstra, A. Y. and Hung, P. Q.: Globalization of water resources: international virtual water flows in relation to crop trade, Global Environ. Change., 15, 45-56, 2005.

Huang, J. and Rozelle, S.: China's accession to WTO and shifts in the agriculture policy, Working Paper 02-002, University of California, Davis, California, 2002.

Jiang, Y.: China's water scarcity, J. Environ. Manage., 90, 31853196, 2009.

Krzywinski, M., Schein, J., Birol, İ., Connors, J., Gascoyne, R., Horsman, D., Jones, S., and Marra, M.: Circos: an information aesthetic for comparative genomics, Genome Res., 19, 16391645, 2009.

Liu, J. and Savenije, H. H. G.: Time to break the silence around virtual-water imports, Nature, 453, 587, 2008.

Liu, J., Zehnder, A. J. B., and Yang, H.: Historical trends in China's virtual water trade, Water Int., 32, 78-90, 2007.
Liu, J., Yang, H., and Savenije, H. H. G.: China's move to higher-meat diet hits water security, Nature, 454, 397, doi:10.1038/454397a, 2008.

Liu, J., Zehnder, A. J. B., and Yang, H.: Global consumptive water use for crop production: the importance of green water and virtual water, Water Resour. Res., 45, W05428, doi:10.1029/2007WR006051, 2009.

Liu, J., Zang, C., Tian, S., Liu, J., Yang, H., Jia, S., You, L., Liu, B., and Zhang, M.: Water conservancy projects in China: achievements, challenges and way forward, Global Environ. Change, 23, 633-643, doi:10.1016/j.gloenvcha.2013.02.002, 2013.

Mountford, H.: Water: the environmental outlook to 2050, presented in the OCED Global Forum on Environment: Making Water Reform Happen, available at: https://community.oecd.org/servlet/ JiveServlet/previewBody/40641-102-1-76036/OECD (last access: 13 June 2013), 2011.

Novo, P., Garrido, A., and Varela-Ortega, C.: Are virtual water "flows" in Spanish grain trade consistent with relative water scarcity, Ecol. Econ., 68, 1454-1464, 2009.

Ozkaynak, B., Pinter, L., van Vuuren, D. P., Bizikova, L., Christensen, V., Floerke, M., Kok, M., Lucas, P., Mangalagiu, D., Alkemade, R., Patterson, T., Shilling, J., Swanson, D., Bassi, A., Feldmann, F., Jager, J., Ochola, Qu, W., Ramakrishna, K., Ringler, C., Ertor, P., and Pervushina, N.: Scenarios and sustainability transformation, UNEP: Global Environment Outlook-5, Nairobi, Kenya, 419-456, 2012.

Piao, S., Ciais, P., Huang, Y., Shen, Z., Peng, S., Li, J., Zhou, Li., Liu, H., Ma, Y., Ding, Y., Friedlingstein, P., Liu, C., Tan, K., Yu, Y., Zhang, T., and Fang, J.: The impacts of climate change on water resources and agriculture in China, Nature, 467, 43-51, doi:10.1038/nature09364, 2010.

Renault, D.: Value of virtual water for food: Principles and features, in: Value of Water Research Report Series No. 12, edited by: Hoekstra, A. Y., UNESCO-IHE, Delft, the Netherlands, 2003.

Shuval, H.: 'Virtual water' in the water resource management of the arid Middle East, Water Resour. Mid. East, 2, 133-139, 2007.

Tamea, S., Allamano, P., Carr, J. A., Claps, P., Laio, F., and Ridolfi, L.: Local and global perspectives on the virtual water trade, Hydrol. Earth Syst. Sci., 17, 1205-1215, doi:10.5194/hess-17-12052013, 2013.

Wang, S. and Zhang, Z.: Effects of climate change on water resources in China, Clim. Res., 47, 77-82, doi:10.3354/cr00965, 2011.

Yang, H. and Zehnder, A.: China's regional water scarcity and implications for grain supply and trade, Environ. Plan. A, 33, 7995, 2001.

Zimmer, D. and Renault, D.: Virtual water in food production and global trade: Review of methodological issues and preliminary results, in: Virtual Water Trade Proceedings of the International Expert Meeting on Virtual Water Trade, edited by: Hoekstra, A. Y., UNESCO-IHE, Delft, the Netherlands, 93-107, 2003. 